\title{
Sedimentary record of sources and accumulation of organic matter in Pyramid Lake, Nevada, over the past 1,000 years
}

\begin{abstract}
We have examined the organic matter contents of two ${ }^{210} \mathrm{~Pb}$-dated cores of sediment from Pyramid Lake for consequences of the historic environmental and limnological changes that have occurred since modern settlement of this region began in the 1850s. Agricultural diversion of Truckee River water has diminished the volume of this saline, terminal lake by one-fourth since 1905 . Organic $\mathrm{C}: \mathrm{N}$ ratios, organic $\delta^{13} \mathrm{C}$ values, and terrigenous: aquatic $n$-alkane ratios indicate that the proportion of land-derived organic matter in sediments has decreased as river flow has decreased. Algal productivity also appears to have decreased since 1930 . Some prehistorical variations in the delivery of organic matter are evident in older sediments. Elevations in the proportion of land plant wax and in $\mathrm{C}: \mathrm{N}$ ratios in sediments deposited A.D. 1200-1400 suggest that contributions of land-derived organic matter were en hanced at this time. Proportions of biomarker $n$-alkanes indicate that grasses were more important than trees and shrubs as the dominant source of land plant waxes during this period, suggesting an interlude of regionally wetter climate.
\end{abstract}

Pyramid Lake is a terminal lake located in the western part of the Great Basin Desert. Its principal source of water is the Truckee River, which drains Lake Tahoe and a number of smaller lakes on the eastern slopes of the Sierra Nevada Mountains (Benson 1994; Hostetler et al. 1994). Water that enters the lake escapes only by evaporation. Because evaporation is relatively constant, the water level of the lake rises and falls in response to variations in runoff in the Truckee River basin.

Three major watershed changes have affected the lake ecosystem since the arrival of modern settlers in this region in the mid-1800s. First, deforestation of much of the eastern slopes of the Sierra Nevada occurred during 1860-1870 to provide timber for the Comstock Lode silver lode in Virginia City, Nevada. Second, the lake level has been lowered by agricultural diversion of Truckee River water, which started on a small scale as early as 1860 but became significant with completion of the Derby Dam in 1905. Lake-level lowering was progressive; it was not until 1940 that the level had dropped sufficiently to cut off flow into the Winnemuca Basin to the east of Pyramid Lake. The third change has been increasing settlement and urbanization of the Reno, Nevada, area, through which the Truckee River flows and that has accelerated since World War II.

Our study was designed to identify consequences of recent environmental changes in Pyramid Lake and its watershed on the delivery and accumulation of organic matter in the lake as recorded in the compositions of sediment cores. These relationships were then used to interpret the environmental conditions that influenced the organic matter contents of prehistoric sections of the sediment record.

Gravity cores were obtained in September 1991 from two locations (Fig. 1), one at the deepest part of the lake (site

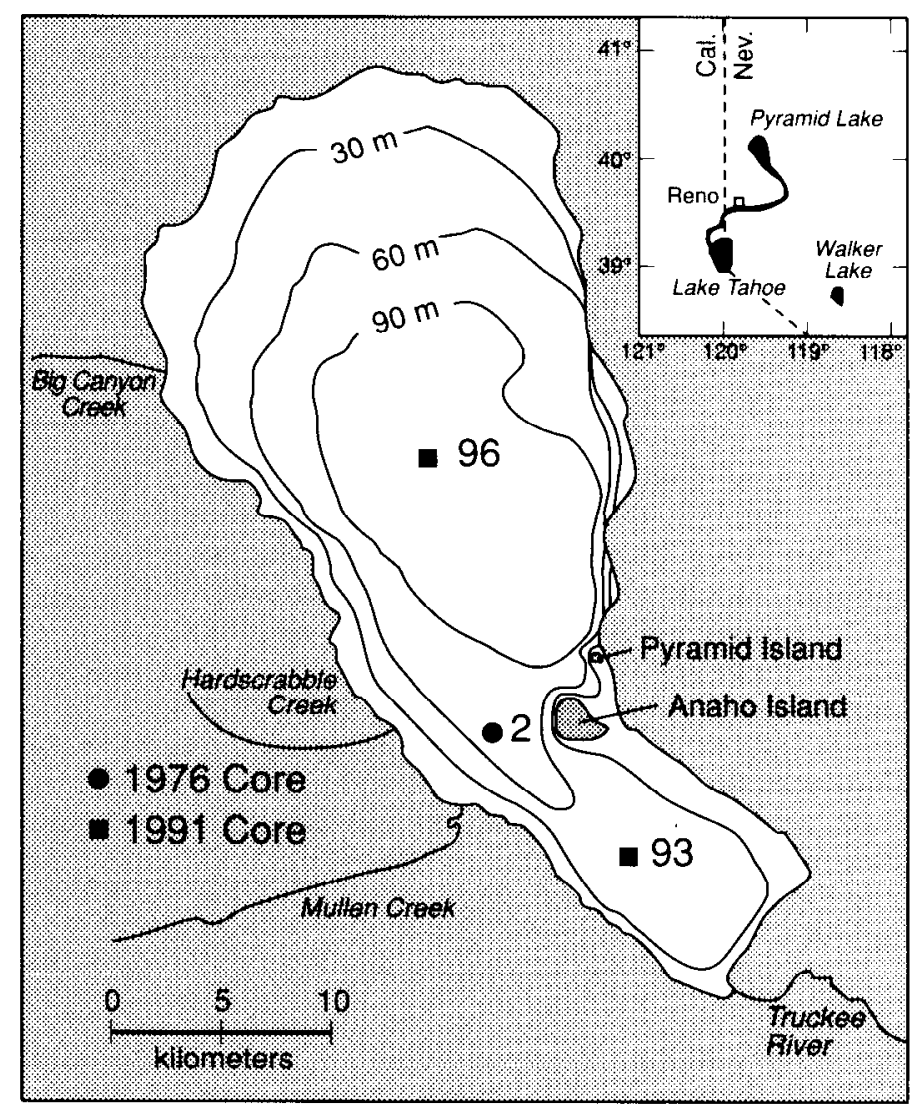

Fig. 1. Location of sites of 1991 Pyramid Lake sediment cores described in this report and of the 1976 core described by Meyers et al. (1980). Pyramid Lake is in the west-central part of the North American Great Basin Desert.

96, water depth $102 \mathrm{~m}$ ) and one at a near-average depth (site 93 , water depth $50 \mathrm{~m}$ ). A $27-\mathrm{cm}$-long core was collected at site 96 and was divided into $1-\mathrm{cm}$ sections over the top 10and $2-\mathrm{cm}$ sections for deeper portions. The site 93 core was $1.1 \mathrm{~m}$ long. It was divided into $2-\mathrm{cm}$ sections for the top 10 $\mathrm{cm}$, and into $4-\mathrm{cm}$ sections for the deeper portions. Core subsections were dried to constant weight at $60^{\circ} \mathrm{C}$ to determine moisture content and to prepare them for subsequent analyses. Times of sediment deposition were estimated from ${ }^{210} \mathrm{~Pb}$ dating of the upper sections of the cores and extrapolation to deeper portions. Lebo et al. (1993, 1994) estimated the bulk sediment mass accumulation rates of the two cores from their average linear sedimentation rates, porosities, and dry bulk densities. Mass accumulation rates of sediment components were calculated from the concentrations of these components and the bulk mass accumulation rates of the two cores.

We collected samples of representative land plants around 
Pyramid Lake and of plankton from the lake for analysis of their organic matter elemental and carbon isotopic compositions. Land plant samples were kept frozen until being dried for analysis. Plankton samples were protected from microbial degradation by adding $\mathrm{IgCl}_{2}$ to the wet samples and using refrigerated storage until they could be dried.

Concentrations of inorganic carbon were determined on the dried sediment samples using a Coulometrics 5010 coulometer equipped with a 5030 carbonate carbon analyzer (cf. Engleman et al. 1985). Inorganic carbon concentrations were converted to carbonate percentages, assuming that all of the inorganic carbon was present as calcium carbonate. Organic carbon concentrations were measured using a Perkin-Elmer $240 \mathrm{CHN}$ analyzer. Samples were first treated with $3 \mathrm{~N} \mathrm{HCl}$ to destroy carbonates. Known weights of dried subsamples were then combusted at $1,100^{\circ} \mathrm{C}$ in the instrument. Organic carbon concentrations are reported on a whole-sediment basis after allowing for the carbonate concentrations measured by the Coulometrics titration. The CHN procedure permits calculation of atomic $\mathrm{C}: \mathrm{N}$ ratios of organic matter from the measured carbon and nitrogen concentrations.

Stable oxygen and carbon isotope ratios of carbonate minerals were determined from analyses done in the Stable Isotope Laboratory at The University of Michigan. Carbon dioxide was released by treatment of samples with phosphoric acid. The ${ }^{18} \mathrm{O}:{ }^{16} \mathrm{O}$ and ${ }^{13} \mathrm{C}:{ }^{12} \mathrm{C}$ ratios of the gas were measured using a Finnigan MAT model 251 mass spectrometer equipped with an automated analysis system. The ${ }^{13} \mathrm{C}:{ }^{12} \mathrm{C}$ ratios of organic carbon were determined with a Finnigan Delta $S$ mass spectrometer after combustion of carbonatefree samples at $800^{\circ} \mathrm{C}$. The ${ }^{15} \mathrm{~N}:{ }^{14} \mathrm{~N}$ ratios of acid-insoluble sediment nitrogen were measured at the NOAA Great Lakes Environmental Research Laboratory with a VG Prism mass spectrometer after similar combustion. NBS standards are routinely and frequently used to calibrate the instruments. $\delta^{13} \mathrm{C}$ and $\delta^{18} \mathrm{O}$ values are reported relative to the PDB standard; $\delta^{15} \mathrm{~N}$ values are reported relative to air.

Total lipid contents were extracted from the dried sediment samples by sonication with dichloromethane. The extracts were evaporated to dryness and heated with methanolic $\mathrm{BF}_{3}$ in a boiling water bath to form the methyl esters of fatty acids. Hydrocarbon and methyl ester biomarker fractions were isolated from the total lipids by alumina over silica gel-column chromatography (Leenheer et al. 1984). These fractions were analyzed with a Hewlett-Packard 5890 gas chromatograph equipped with a $20-\mathrm{m}$ DB-1 capillary column, a flame ionization detector, and an automatic injector system. Quantification and identification of individual hydrocarbon and fatty acid components were achieved using internal standards added before extraction and detector response factors determined from quantitative mixtures of known compounds. Data have been corrected for the small amounts of procedural contaminants determined from blank analyses.

The bulk mass accumulation rates of sediments average $14 \mathrm{mg} \mathrm{cm}^{-2} \mathrm{yr}^{-1}$ at site 96 in the central basin of the lake and $47 \mathrm{mg} \mathrm{cm}^{-2} \mathrm{yr}^{-1}$ at site 93 at the southern end (Lebo et al. 1994). The difference results from sediments in the deep basin that are finer in size and that have a greater porosity than those in the shallower southern end (Lebo and Reuter
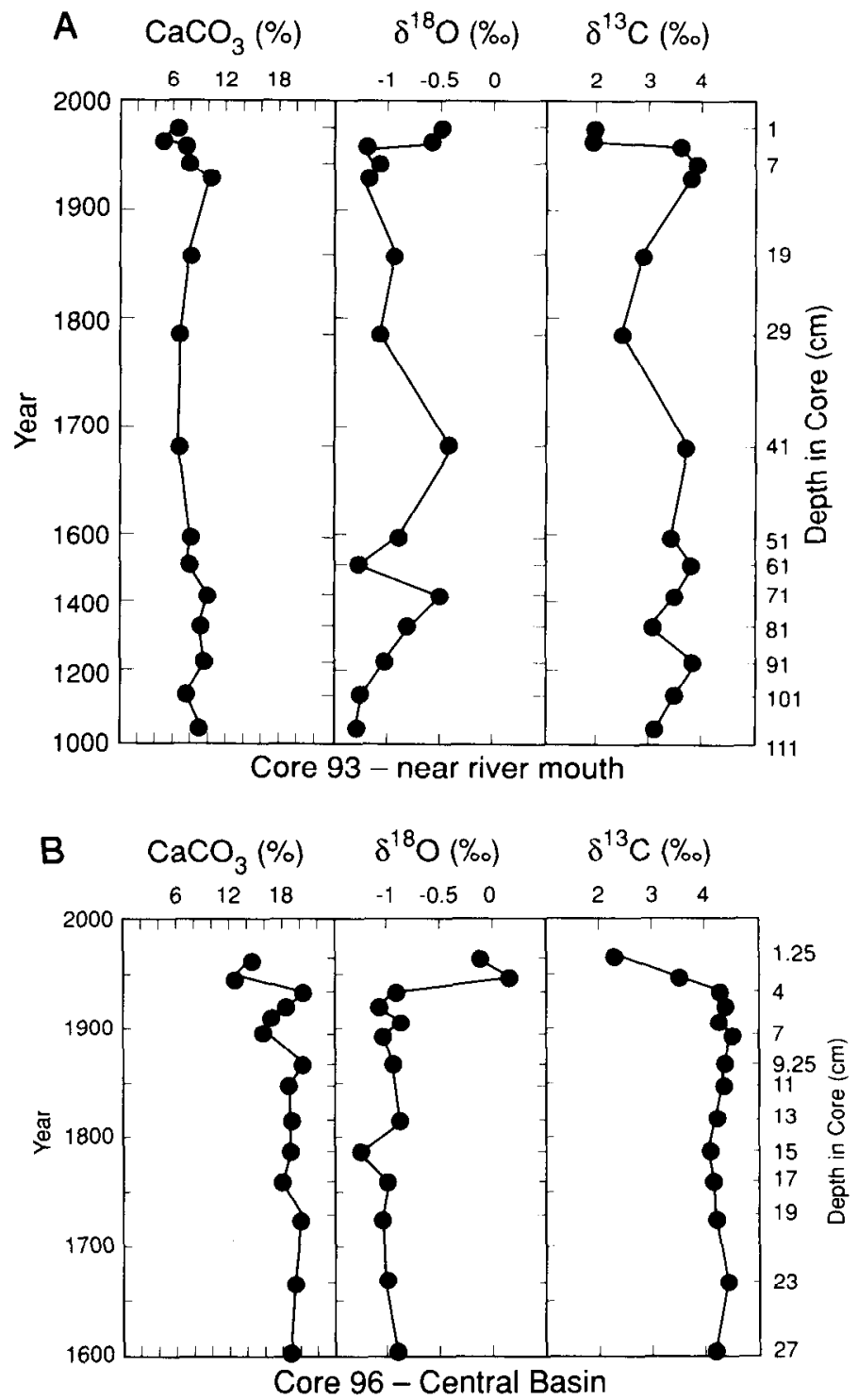

Fig. 2. Calcium carbonate concentrations and $\delta^{11} \mathrm{C}$ and $\delta^{1 \times} \mathrm{O}$ values in sediments from cores 93 and 96 from Pyramid Lake. Note change in age/depth axis of core 93 .

1995). The distinctive sediment accumulation rates and grain size distributions reflect depth-related differences in the delivery of sediments to these two locations, and other sediment properties are similarly affected by this parameter.

The calcium carbonate concentrations are lower in sediments deposited since 1930 at both core sites (Fig. 2). Older sediments at both locations show little variation in $\mathrm{CaCO}_{3}$ concentration, but the concentrations are more than twice as great at deep-lake site 96 than at site 93 at the southern end. The difference in composition between the two sites reflects turbulent suspension of finer sized, carbonate-rich sediment particles at locations shallower than $60 \mathrm{~m}$ and their downslope transport to the deeper central basin (Lebo and Reuter 1995; Tenzer et al. 1997). In addition, the decreased carbonate concentrations from the sediment winnowing at site 93 is augmented by delivery of diluting noncarbonate sediment 
Table 1. Mass accumulation rates of $\mathrm{CaCO}_{3}$, total organic carbon (TOC), total $n$-alkanes (Total HC), lake-derived hydrocarbons $\left(\sum n-\mathrm{C}_{17}+n-\mathrm{C}_{19}+n-\mathrm{C}_{21}\right)$, and land-derived hydrocarbons $\left(\sum n-\mathrm{C}_{27}\right.$ $+n-\mathrm{C}_{29}+n-\mathrm{C}_{31}$ ) for sediments from cores 93 and 96 from Pyramid Lake (n.d., not determined).

\begin{tabular}{|c|c|c|c|c|c|c|}
\hline $\begin{array}{l}\text { Core } \\
\text { depth } \\
(\mathrm{cm})\end{array}$ & Year & $\begin{array}{c}\mathrm{CaCO}_{3} \\
(\mathrm{mg} \\
\mathrm{cm}^{-2} \\
\left.\mathrm{yr}^{-1}\right) \\
\end{array}$ & $\begin{array}{l}\text { TOC } \\
(\mathrm{mg} \\
\mathrm{cm}^{-2} \\
\left.\mathrm{yr}^{-1}\right)\end{array}$ & $\begin{array}{c}\text { Total } \\
\mathrm{HC} \\
(\mathrm{ng} \\
\mathrm{cm}^{-2} \\
\left.\mathrm{yr}^{-1}\right)\end{array}$ & $\begin{array}{c}\text { Lake } \\
\mathrm{HC} \\
(\mathrm{ng} \\
\mathrm{cm}^{-2} \\
\left.\mathrm{yr}^{-1}\right)\end{array}$ & $\begin{array}{c}\text { Land } \\
\mathrm{HC} \\
(\mathrm{ng} \\
\mathrm{cm}^{-2} \\
\left.\mathrm{yr}^{-1}\right)\end{array}$ \\
\hline \multicolumn{7}{|c|}{ Core 96 , central basin $(102 \mathrm{~m})$} \\
\hline 1.25 & 1963 & 2.08 & 0.44 & 63 & 5 & 15 \\
\hline 2.75 & 1945 & 0.57 & n.d. & n.d. & n.d. & \\
\hline 4.0 & 1930 & 2.91 & 0.45 & 49 & 4 & 20 \\
\hline 5.0 & 1918 & 2.59 & 0.44 & 60 & 6 & 21 \\
\hline 6.0 & 1905 & 2.34 & 0.43 & 65 & 4 & 19 \\
\hline 7.0 & 1893 & 2.27 & 0.45 & 90 & 4 & 24 \\
\hline 9.25 & 1863 & 2.89 & 0.51 & 42 & 3 & 11 \\
\hline 11.0 & 1839 & 2.67 & 0.50 & 57 & 6 & 16 \\
\hline 13.0 & 1811 & 2.64 & 0.51 & 46 & 4 & 14 \\
\hline 15.0 & 1783 & 2.64 & 0.45 & 65 & 3 & 19 \\
\hline 17.0 & 1755 & 2.55 & 0.48 & 33 & 1 & 10 \\
\hline 19.0 & 1725 & 2.85 & 0.47 & n.d. & n.d. & n.d. \\
\hline 23.0 & 1664 & 2.75 & 0.43 & 108 & 7 & 26 \\
\hline 27.0 & 1603 & 2.69 & 0.41 & 80 & 4 & 28 \\
\hline \multicolumn{7}{|c|}{ Core 93 , southern end $(50 \mathrm{~m})$} \\
\hline 1.0 & 1981 & 3.09 & 1.18 & 172 & 28 & 58 \\
\hline 3.0 & 1967 & 2.25 & 0.68 & 496 & 21 & 96 \\
\hline 5.0 & 1962 & 3.60 & 0.79 & 257 & 11 & 66 \\
\hline 7.0 & 1945 & 3.59 & 0.91 & 93 & 6 & 40 \\
\hline 9.0 & 1930 & 4.78 & 1.19 & 275 & 5 & 106 \\
\hline 19.0 & 1864 & 3.79 & 0.72 & n.d. & n.d. & n.d. \\
\hline 29.0 & 1789 & 3.28 & 0.70 & 258 & 6 & 77 \\
\hline 41.0 & 1690 & 3.13 & 0.77 & 229 & 10 & 69 \\
\hline 51.0 & 1604 & 3.73 & 0.76 & 165 & 5 & 56 \\
\hline 61.0 & 1515 & 3.60 & 0.70 & 153 & 5 & 59 \\
\hline 71.0 & 1423 & 4.66 & 0.70 & 143 & 13 & 48 \\
\hline 81.0 & 1326 & 4.24 & 0.68 & n.d. & n.d. & n.d. \\
\hline 91.0 & 1228 & 4.52 & 0.75 & 161 & 5 & 107 \\
\hline 101.0 & 1129 & 3.48 & 0.66 & 123 & 5 & 52 \\
\hline 111.0 & 1031 & 4.31 & 0.70 & 312 & 9 & 90 \\
\hline
\end{tabular}

materials by the Truckee River to the southern end of the lake. The difference in concentrations nearly compensates for the threefold difference in sediment accumulation rates between the two sites. The mass accumulation rate of $\mathrm{CaCO}_{3}$ at site 93 is less than twice that at site 96 (Table 1).

Diminished carbonate concentrations and mass accumulation rates in recent sediments at both locations suggest that delivery of diluting material to the lake bottom has been magnified by lowered lake level, even though river volume has been decreased by nearly half. The amount of $\mathrm{CaCO}_{3}$ decrease is more at the deep-lake location than at the location closer to the river mouth, indicating the importance of sediment redeposition from shallower locations.

The $\delta^{18} \mathrm{C}$ and $\delta^{13} \mathrm{C}$ values of the waters of Pyramid Lake are increased relative to the sources of water to this terminal lake by evaporative distillation (Table 2). The isotopic compositions of the waters of Pyramid Lake consequently reflect the hydrologic balance of the lake (Benson 1994), and they
Table 2. Stable isotopic compositions of various sources of water to Pyramid Lake and from different parts of the lake: $\delta^{13} \mathrm{O}$ values are of water, $\delta^{13} \mathrm{C}$ values are of total dissolved inorganic carbon (from Benson 1994; Benson et al. 1995; W. P. Patterson and C. N. Drummond unpubl. data from 1991 samples).

\begin{tabular}{lcc}
\hline \hline \multicolumn{1}{c}{ Water sample } & $\delta^{18} \mathrm{O}(\% \circ$, SMOW $)$ & $\delta^{13} \mathrm{C}(\% \circ, \mathrm{PDB})$ \\
\hline Truckee River & -11.2 & -10.8 \\
Farad & $-10.3 \pm 1.7$ & - \\
Farad $(n=55)$ & -11.7 & -13.2 \\
Wadsworth Bridge & -10.6 & - \\
Nixon Bridge & $-10.4 \pm 0.8$ & - \\
Nixon ( $n=61)$ & & - \\
Precipitation into Pyramid Lake & & \\
Sutcliffe ( $n=52)$ & $-9.8 \pm 4.4$ & - \\
Spring water at Pyramid Lake & & -8.2 \\
Pyramid Island & -9.6 & -9.9 \\
Popcorn Rocks & -9.0 & - \\
Blanc Tetons & -14.6 & \\
Needles hot spring & -12.2 & \\
Needles "geyser" & -11.4 & -0.4 \\
Water from Pyramid Lake & & -1.4 \\
Pyramid Island & 0.1 & - \\
South end & -0.1 & -0.6 \\
Sutcliffe & 0.1 & \\
Warrior Point & 0.1 & \\
\hline
\end{tabular}

in turn affect the isotopic compositions of carbonate precipitates and aquatic organic matter.

The Pyramid Lake sedimentary carbonate $\delta^{18} \mathrm{O}$ values indeed seem to record changes in the lake water volume. Surface sediments are isotopically heavier than sediments located deeper in the cores (Fig. 2), reflecting the diminished inflow of ${ }^{18} \mathrm{O}$-depleted river water and consequent evaporative loss of ${ }^{16} \mathrm{O}$ since 1905 . Two prehistoric intervals of possibly lowered lake level are indicated by greater $\delta^{18} \mathrm{O}$ values in sediments corresponding to circa A.D. 1700 and 1400 in core 93, but these lowered levels are questionable inasmuch as the 1700 event is not duplicated in the core $96 \delta^{18} \mathrm{O}$ values.

Carbonates deposited since 1930 have less positive $\delta^{13} \mathrm{C}$ values than do older carbonates (Fig. 2), which is opposite from what would be expected from the decreased inflow of isotopically light river water. Furthermore, the $\delta^{13} \mathrm{C}$ values of older sediments are slightly different at the two locations, averaging $4.0 \%$ in core 93 and $4.5 \%$ in deep-water core 96. The origin of most of the carbonates is from inorganic aragonite precipitation, which occurs in the epilimnion (Galat and Jacobsen 1985). This water is presumably spatially well mixed and should not isotopically differ from one part of the lake to another. It is possible, however, that the proportion of biogenic carbonates differs at the two core locations. Tenzer et al. (1997) show that ostracod $\delta^{13} \mathrm{C}$ compositions are offset from bulk carbonate values in Pyramid Lake sediments by about $+3 \%$. The sediments from core 96 , which are isotopically heavier by $\sim 0.5 \%$, also have greater organic matter concentrations (Fig. 3) and could therefore support larger numbers of benthic fauna, such as ostracods. Another factor is that hydrodynamic sorting evidently occurs to set- 

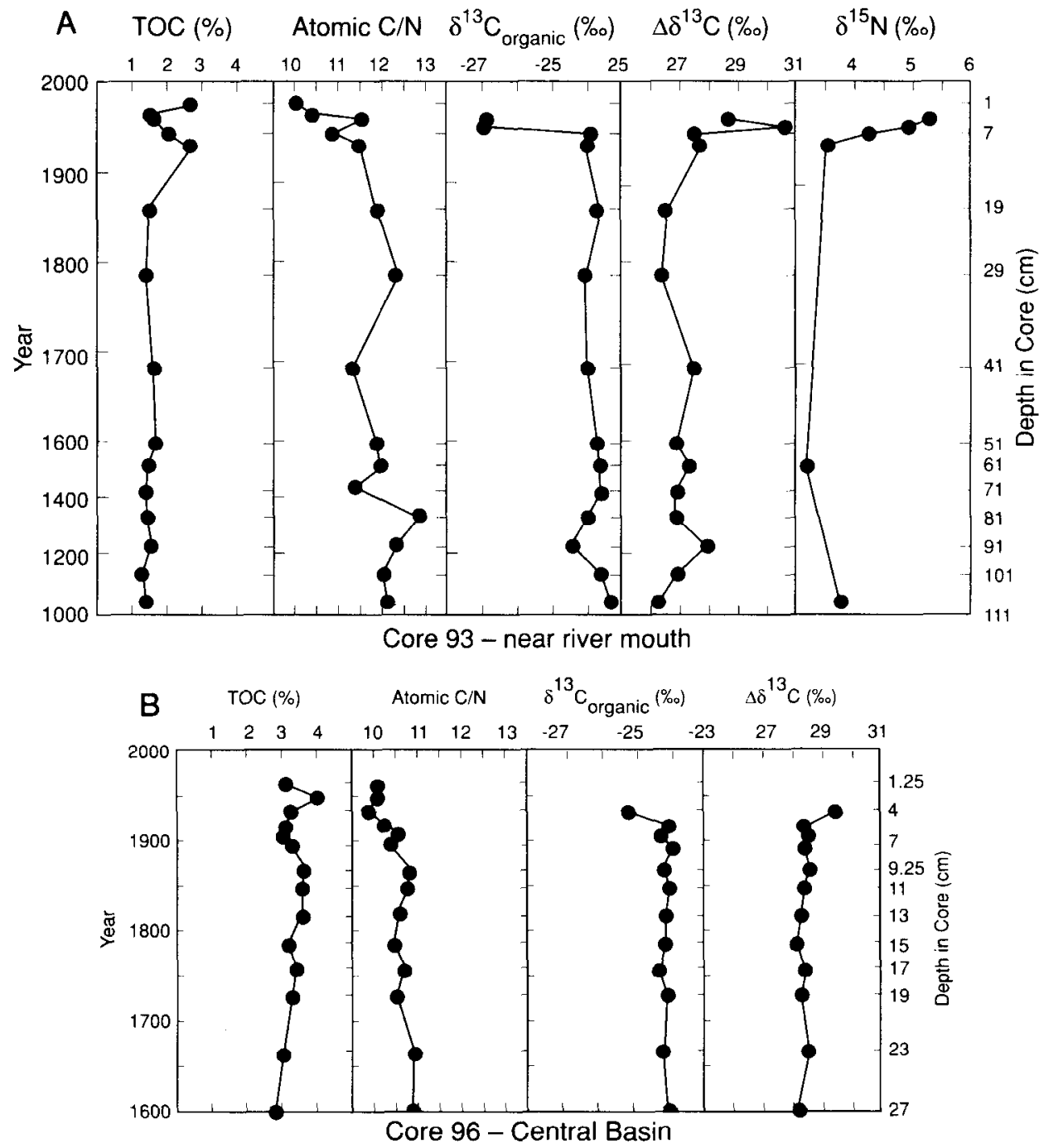

Fig. 3. Organic carbon concentrations and organic matter atomic $\mathrm{C}: \mathrm{N}$ ratios and $\delta^{13} \mathrm{C}$ values in sediments from cores 93 and 96 from Pyramid Lake. $\Delta \delta^{13} \mathrm{C}$ is the difference between carbonate and organic carbon $\delta^{13} \mathrm{C}$ values. Carbonate-free $\delta^{15} \mathrm{~N}$ values are presented for sediments from core 93 near the mouth of the Truckee River. Note change in age/depth axis of core 93.

tling and resuspended carbonate particles in Pyramid Lake (Lebo and Reuter 1995), and it concentrates isotopically heavier particles in the deeper parts of the lake (Tenzer et al. 1997). Such particles may be formed during periods of weaker thermal stratification of the lake, or they may be of finer size than isotopically lighter particles. Satisfactory interpretation of the carbonate $\delta^{13} \mathrm{C}$ values remains elusive, yet the decreased values seen in both cores at circa 1930 indicate that an important change occurred in the Pyramid Lake ecosystem as lake level continued to drop at that time.

Lebo et al. (1993) estimated that $94 \%$ of the organic carbon delivered to modern Pyramid Lake is derived from aquatic production. A large part of the aquatic organic matter is produced during midsummer blooms of the cyanophyte Nodularia spumigena (Galat 1986). Land-based productivity in the immediately surrounding desert areas is low, although the Truckee River does transport land-derived organic debris to the lake. The flux of river-borne organic matter is season- ally variable but seldom large; Lebo et al. (1993) estimated that its annual average is $5 \%$ of the total flux. The remaining $1 \%$ of organic carbon flux is from a variety of minor sources, including tumbleweed that is blown into the lake (Galat 1986), which is a source that is peculiar to desertic lakes.

We anticipated that past changes to the lake and watershed environments would be evident in the history of accumulation of organic matter in Pyramid Lake sediments. We found that the locations of the sediment core sites were also a factor in organic matter accumulation. The concentrations of organic carbon are higher in sediments from deep-water core 96 than in those from core 93, which is nearer to the mouth of the Truckee River. Values of between 3 and $4 \mathrm{wt} \%$ are found throughout core 96 (Fig. 3). In contrast, concentrations are between 1 and $2 \%$ throughout most of core 93, but they increase to nearly $3 \%$ in some post-1900 sediments. The higher organic carbon concentrations found in deep-water core 96 follow the pattern of increasing concentrations with 
Table 3. Atomic $\mathrm{C}: \mathrm{N}$ ratios and $\delta^{13} \mathrm{C}$ values of plants that are potential sources of organic matter to Pyramid Lake sediments.

\begin{tabular}{lrc}
\hline \hline \multicolumn{1}{c}{ Plant sample } & Atomic C:N $\delta^{13} \mathrm{C}(\% \circ \mathrm{PDB})$ \\
\hline $\mathrm{C}_{3}$ land plants & 38 & -26.7 \\
Willow leaves & 102 & -25.8 \\
Aspen leaves & 62 & -27.9 \\
Poplar leaves & 22 & -25.0 \\
Cottonwood leaves & 47 & 22.5 \\
Junipcr nccdles & 42 & -24.8 \\
Piñon needles & 37 & -26.4 \\
Big sage leaves & 39 & -23.4 \\
Mormon tea leaves & 30 & -23.1 \\
Mountain mahogany leaves & 57 & -25.2 \\
Rabbit bush leaves & - & -25.1 \\
Greasewood twigs & - & -21.6 \\
Greasewood seeds & & \\
C 4 land plants & 68 & -12.5 \\
Tumbleweed stems & 160 & -14.1 \\
Salt grass & - & -14.1 \\
Shadscale leaves & - & -12.9 \\
Shadscale twigs & - & -13.1 \\
Shadscale seeds & - & -14.7 \\
Green molly leaves & - & -13.3 \\
Green molly twigs & - & -13.6 \\
Green molly seeds & - & -30.1 \\
Aquatic plants & -18.6 & \\
Mixed plankton (May 1986) & - & -28.3 \\
Mixed plankton (May 1989) & - & \\
Nodularia (May 1986) & - & \\
\hline
\end{tabular}

greater water depth in Pyramid Lake (Tenzer et al. 1997). Surficial sediments at $50 \mathrm{~m}$, the depth at core 93 , typically contain between 1 and $2 \%$ organic carbon, whereas those from depths of $90-100 \mathrm{~m}$, such as at core 96 , have between 3 and $4 \%$ organic carbon. This pattern also follows a general decrease in average sediment particle size in deeper parts of the lake (Lebo and Reuter 1995) and reflects sediment resuspension and redeposition.

Unlike the concentrations, the mass accumulation rates of organic carbon are higher in core 93 sediments than in those from core 96 (Table 1). The faster sedimentation rate at site 93 may improve preservation of organic matter (cf. Emerson and Hedges 1988; Meyers and Ishiwatari 1993). It is also possible that this site may receive more fluvial land-derived organic matter, which would be less subject to in situ degradation (cf. Meyers and Ishiwatari 1993). Because the Truckee River provides only $5 \%$ of the total organic carbon flux to the lake (Lebo et al. 1993), this possibility may be a small factor in creating the larger mass accumulation rate found in core 93 sediments.

Organic matter from aquatic sources can be distinguished from land-derived organic matter by $\mathrm{C}: \mathrm{N}$ ratios (e.g. Meyers 1994). Our summary of $C: N$ values of representative plants in and around Pyramid Lake shows that phytoplankton have $\mathrm{C}: \mathrm{N}$ ratios of $<15$ whereas vascular land plants, which are rich in cellulose and poor in proteins, have $\mathrm{C}: \mathrm{N}$ ratios of 22-160 (Table 3). The $\mathrm{C}: \mathrm{N}$ ratios in sediments from core 96 in the deep basin are consistently between $\sim 10$ and 11 (Fig. 3), indicating dominance of lake-derived organic mat- ter. A small shift from values of $\sim 11$ in pre-1900 sediments to values of $\sim 10$ in post- 1900 sediments coincides with the agricultural diversion of Truckee River water. This diversion evidently diminished contributions of river-borne, land-derived organic matter to the entire lake system. $\mathrm{C}: \mathrm{N}$ ratios in sediments from core 93, which is closer to the mouth of the Truckee River (Fig. 1), are somewhat higher than those in core 96. Until after 1900, the values were between 11 and 13 (Fig. 3). These slightly higher ratios suggest that the sediments in this part of the lake received more land-derived organic matter, although their principal source has always been from algae. The shift to lower $\mathrm{C}: \mathrm{N}$ ratios in more recent sediments confirms that fluvial delivery of land-derived organic matter has been diminished since completion of the Derby Dam in 1905.

Most photosynthetic plants incorporate carbon into organic matter using the $\mathrm{C}_{3}$ Calvin pathway, which preferentially incorporates ${ }^{12} \mathrm{C}$ into organic matter and produces a shift of about $-20 \%$ from the carbon isotope ratio of the inorganic carbon pool. Some desert plants use the $\mathrm{C}_{4}$ Hatch-Slack pathway, which has a lower isotope shift of -8 to $-12 \%$. Land-derived organic matter produced by plants using the $\mathrm{C}_{3}$ pathway typically has an average $\delta^{13} \mathrm{C}$ (PDB) value of about $-28 \%$ as opposed to $-14 \%$ o by those that use the $\mathrm{C}_{4}$ pathway (cf. O'Leary 1988). The distinctive $\delta^{13} \mathrm{C}$ difference in organic matter from $\mathrm{C}_{3}$ and $\mathrm{C}_{4}$ is apparent in plants from around Pyramid Lake (Table 3). Plankton-derived organic matter is isotopically similar to organic matter from the $\mathrm{C}_{3}$ plants from near Pyramid Lake, but it is dissimilar to material from $\mathrm{C}_{4}$ plants (Table 3 ).

The sedimentary organic $\delta^{13} \mathrm{C}$ values in both cores are monotonous over most of the pre-1900 depositional records. Values from core 96 are slightly smaller and those from core 93 are slightly greater than $-24 \%$ (Fig. 3). These isotopic profiles indicate that the organic matter from both core sites originated predominantly from $\mathrm{C}_{3}$ plants, and they eliminate both $\mathrm{C}_{4}$ land plants and Nodularia from being important sources of organic carbon to the lake bottom. These data, combined with the $\mathrm{C}: \mathrm{N}$ data, agree with the estimate that most of the organic carbon delivered to the lake sediments was from algal productivity (Lebo et al. 1993). A shift to more negative $\delta^{13} \mathrm{C}$ values appears in post-1900 sediments at both locations, which is consistent with diminished algal productivity (Fogel and Cifuentes 1993). One consequence of the decreased river flow that started in 1905 apparently has been the decreased fluvial supply of nutrients to Pyramid Lake.

The isotopic fractionation between carbonate carbon and organic carbon $\left(\Delta \delta^{13} \mathrm{C}\right)$ remains at $\sim 28.5 \%$ o in core 96 and $\sim 27.0 \%$ in core 93 for sediments deposited prior to 1900 ; this difference increases to $\sim 29.5$ and $\sim 28.7 \%$, respectively, in more recent sediments (Fig. 3). An older increase in the difference is found in sediments deposited circa A.D. 1200 (Fig. 3). In comparison, Benson et al. (1991) reported a difference of $\sim 28 \%$ between sedimentary organic carbon and carbonate carbon in Walker Lake and fractionations of about $-24 \%$ for Nodularia spumagena and of $-31 \%$ for mixed plankton living in the lake waters. Similarly, Hollander and McKenzie (1991) found that the $\Delta \delta^{13} \mathrm{C}$ changed from $22 \%$ during blooms of blue-green algae to $26-30 \%$ during diatom 
blooms in Lake Greifen, Switzerland. The change to a larger $\Delta \delta^{13} \mathrm{C}$ consequently may indicate that the organic matter source to the Pyramid Lake sediments has shifted more toward plankton since river flow has been diminished. An earlier, similar shift toward greater importance of plankton-derived organic matter may also be indicated by the enhanced $\Delta \delta^{13} \mathrm{C}$ found in sediment deposited around A.D. 1200. Analogous to conditions since river diversion began in 1905, this period may have been one of prehistoric, lowered lake levels. The earlier enhancement of isotopic fractionation may therefore record a time of diminished fluvial delivery of organic matter, concurrent increased proportion of aquatic delivery of organic matter, and possible change of the algal assemblage in Pyramid Lake.

The $\delta^{15} \mathrm{~N}$ value of dissolved nitrate is $+7 \% 0-10 \%$, whereas atmospheric molecular nitrogen has a value of $0 \%$ (cf. Peters et al. 1978). This isotopic difference between sources of nitrogen to aquatic and continental primary producers is preserved in the organic matter of plankton $\left(\delta^{15} \mathrm{~N}\right.$ of $+8 \%$ ) and $\mathrm{C}_{3}$ land plants $\left(\delta^{1.5} \mathrm{~N}\right.$ of $+1 \%$ ) (Peterson et al. 1985) and is another potential indicator of changes in the delivery of organic matter to the sediments of Pyramid Lake. Our $\delta^{15} \mathrm{~N}$ determinations are limited to six intervals from core 93 , but these data are sufficient to show a change from values between +3 and $+4 \%$ in sediments deposited prior to 1930 to progressively more positive values in younger sediments (Fig. 3). Diversion of the Truckee River has diminished delivery of isotopically light land-derived organic matter, thereby increasing the proportion of isotopically heavy lakederived material. Progressively lower $\mathrm{C}: \mathrm{N}$ ratios (Fig. 3) support a change to delivery of greater relative proportions of algal organic matter in post-1930 core 93 sediments. An enhanced fraction of lake-derived material is therefore involved in the shift to larger $\delta^{15} \mathrm{~N}$ values of the sediment organic matter.

The magnitude of the $\delta^{15} \mathrm{~N}$ shift, however, is much larger than would be expected from the relatively small change in $\mathrm{C}: \mathrm{N}$ ratios; algal organic matter has dominated sediment compositions throughout the core 93 record. An additional factor in the shift to larger $\delta^{15} \mathrm{~N}$ values is probably decreased isotopic discrimination against ${ }^{15} \mathrm{~N}$, as fluvial replenishment of dissolved nitrate diminished after diversion of the Truckee River in 1905. Consequently, the nitrogen isotope contents of the core 93 sediments record both a shift in proportions of land-derived and aquatic organic matter and diminished availability of dissolved nitrogen to the lake algae as fluvial supply has decreased.

The hydrocarbon compositions of lake sediments can provide relatively robust histories of changes in aquatic and watershed biological communities. Two factors combine to give hydrocarbons introduced to lake sediments long residence times. First, higher molecular-weight hydrocarbon components have relatively low water solubilities and consequently associate strongly with sediment particles. Second, hydrocarbons as a group are less susceptible to degradation than are most forms of organic matter because they lack the oxygen- and nitrogen-containing functional groups that impart chemical reactivity. Comparison of the apparent decomposition rates of different organic matter components in Lake Michigan sediment traps, for example, has shown that the

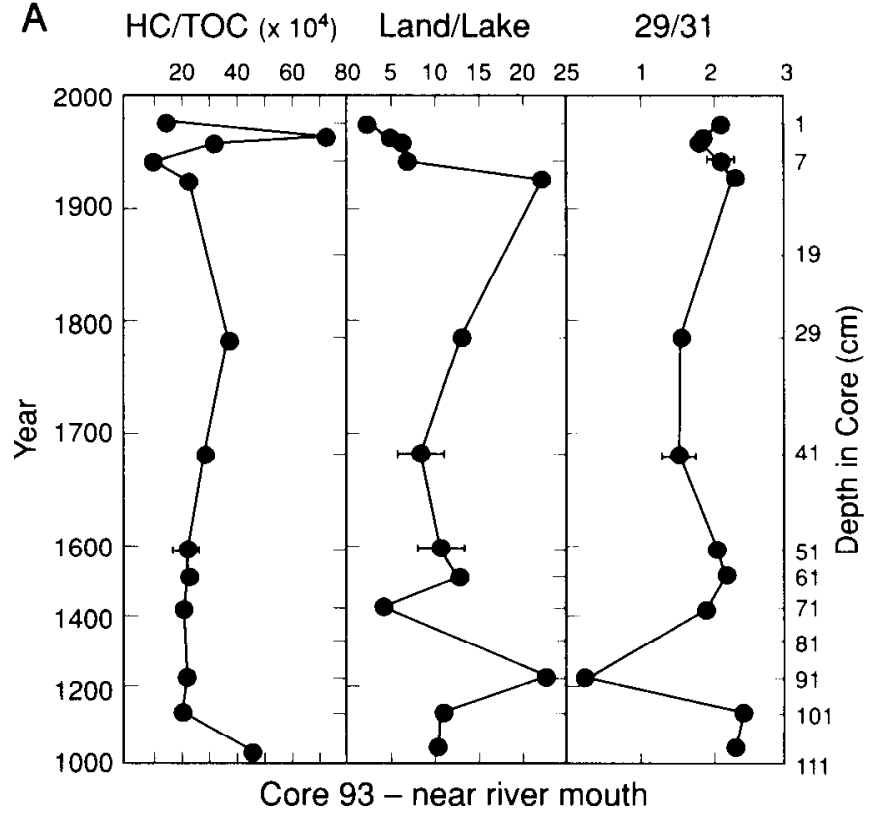

B

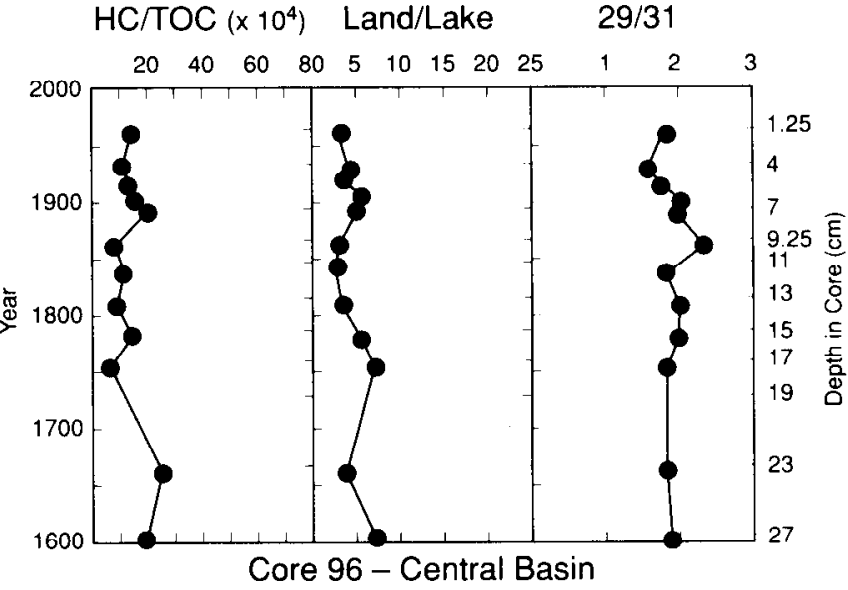

Fig. 4. Extractable $n$-alkane hydrocarbon compositions of sediments from cores 93 and 96 from Pyramid Lake. Concentrations are reported as milligram total hydrocarbons per gram of organic carbon. Land: lake ratios represent land-derived/aquatic sources of hydrocarbons and are calculated as $\left(n-\mathrm{C}_{27}+n-\mathrm{C}_{24}+n-\mathrm{C}_{31}\right) /\left(n-\mathrm{C}_{17}\right.$ $\left.+n-\mathrm{C}_{19}+n-\mathrm{C}_{21}\right)$. The ratio of $n-\mathrm{C}_{29}$ to $n-\mathrm{C}_{31}$ alkanes represents tree and shrub hydrocarbon wax contributions vs. grass wax contributions. Note change in age/depth axis of core 93

apparent degradation rate of hydrocarbons is two to three times slower than the decomposition rate of total organic matter (Meyers and Eadie 1993).

Concentrations of total hydrocarbons extracted from Pyramid Lake sediments are expressed relative to total organic carbon concentrations to compensate for the difference in organic matter content of the two cores. The organic matter present in core 93 contains proportionally more hydrocarbons than does the organic matter at the deep-basin location (Fig. 4). The mass accumulation rates of hydrocarbons are more than three times greater in the sediments of core 93 than in those of core 96 (Table 1). The record of total organic carbon accumulation in these two cores is fairly uniform 

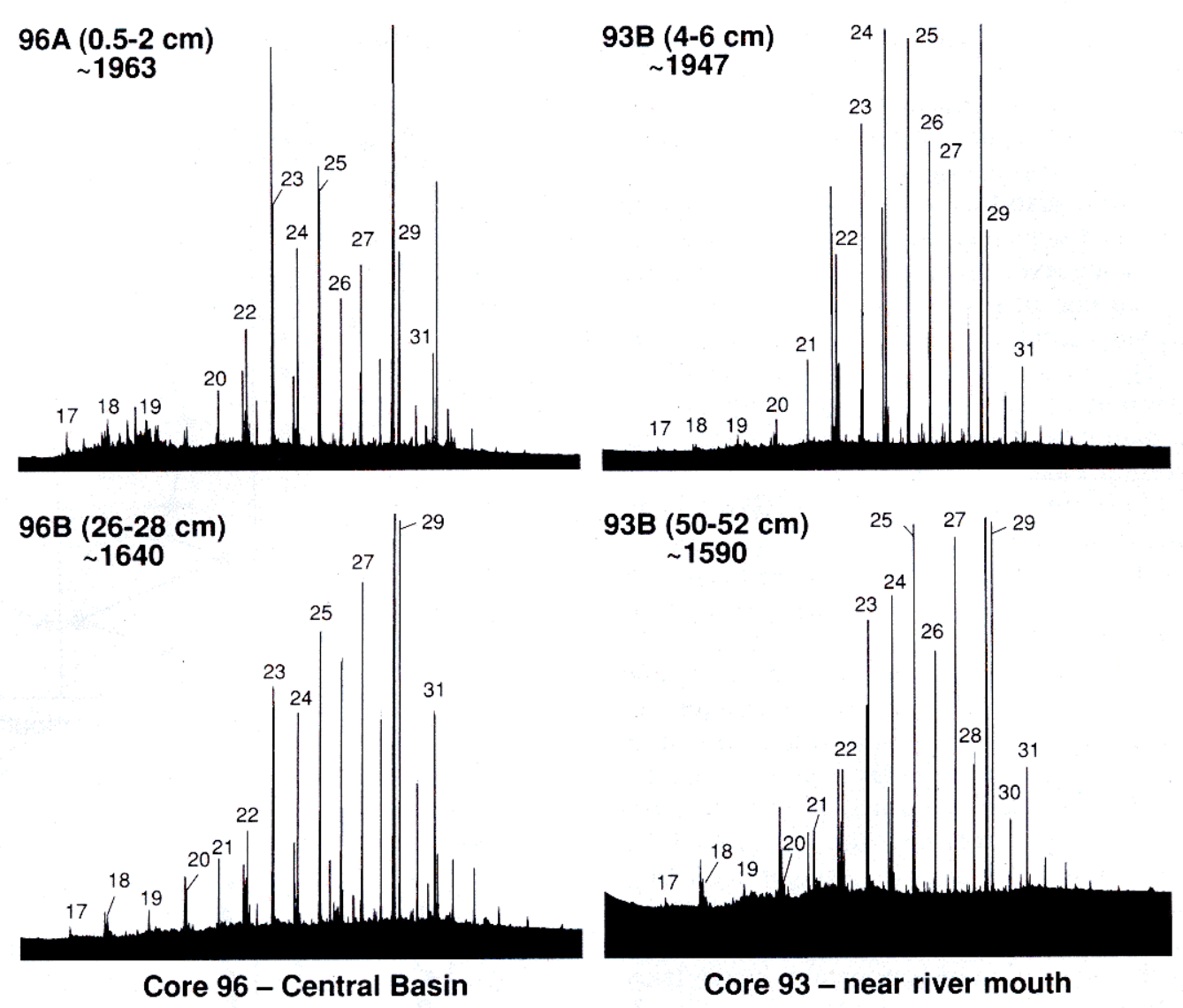

Fig. 5. Chromatograms of hydrocarbons extracted from sediments of Pyramid Lake. $n$-Alkanes are identified by the number of carbon atoms they contain. Flat baseline indicates the lack of detectable petroleum contamination of these sediments by the absence of the unresolved complex mixture.

(Fig. 3), indicating that variations in preservation have not been important. Instead, the hydrocarbon accumulation records indicate that the proportions of hydrocarbons in the deposited organic matter have been different at the two locations and have fluctuated over time. Moreover, we postulate that hydraulic sorting of sediment particles as a result of resuspension and resettling has contributed to the difference in hydrocarbon loadings at the two sites.

The common abundance of waxy coatings on land plants results in land-derived organic matter having higher proportional hydrocarbon contents than algal organic matter (cf. Eglinton and Hamilton 1963; Cranwell et al. 1987; Goossens et al. 1989; Meyers and Ishiwatari 1993). Greater amounts of total hydrocarbons in the sediments of core 93 suggest that more land-derived organic matter has been delivered to this location, which is consistent with the somewhat larger $\mathrm{C}: \mathrm{N}$ ratios of these sediments (Fig. 3). Similar elevations in the proportions of hydrocarbons in older sediments may record former episodes of greater delivery of land-derived organic matter to Pyramid Lake.

The principal sources of hydrocarbons to lake sediments can be identified by their distinctive $n$-alkane chainlength distributions. The hydrocarbon compositions of photosynthetic algae and bacteria are dominated by the $\mathrm{C}_{17}$ biomarker $n$-alkane (e.g. Blumer et al. 1971; Weete 1976; Giger et al.
1980; Cranwell et al. 1987). Hydrocarbons contributed from vascular plants on land or along the edges of lakes contain large proportions of $\mathrm{C}_{27}, \mathrm{C}_{29}$, and $\mathrm{C}_{31} n$-alkanes that originated in the epicuticular waxy coatings of these plants (e.g. Eglinton and Hamilton 1963, 1967; Cranwell 1973; Cranwell et al. 1987; Rieley et al. 1991). Land plant $n$-alkanes dominate the distributions of hydrocarbons extracted from both modern and older sediments in cores 93 and 96 (Fig. 5). The dominance of land-derived hydrocarbon components seemingly conflicts with bulk organic matter $\mathrm{C}: \mathrm{N}$ ratios of $\sim 10$ that indicate that most of the sediment organic matter originated from algal production. Because contributions of land-derived organic matter typically contain higher proportions of $n$-alkanes than do those from aquatic algae (cf. Cranwell et al. 1987; Goossens et al. 1989; Meyers and Ishiwatari 1993), $n$-alkane distributions typically over exaggerate terrigenous contributions.

We used a ratio of the known biomarker $n$-alkane source indicators to identify changes in the terrigenous/aquatic mixture of hydrocarbons in the cores of Pyramid Lake sediment. The ratios of land-to-lake-derived $n$-alkanes were estimated as

$$
\text { Land: lake ratio }=\left(\mathrm{C}_{27}+\mathrm{C}_{29}+\mathrm{C}_{31}\right) /\left(\mathrm{C}_{17}+\mathrm{C}_{19}+\mathrm{C}_{21}\right) \text {. }
$$

This ratio is useful for indicating changes in the relative 
contributions of hydrocarbons from land and lake flora, but it must be remembered that the absolute amounts of organic matter from terrigenous sources are overrepresented by the $n$-alkane components.

The $n$-alkane land: lake ratios are consistently larger than 1 in all sediment intervals from cores 93 and 96 (Fig. 4), thereby verifying the dominance of land-derived components that is indicated by the chromatographic distributions (Fig. 5). The ratios fluctuate narrowly between 5 to 10 in core 96 sediments, but fluctuate widely between 3 to 23 in Core 93 . The lowest value in core 93 occurs in the most modern sediment interval (A.D. 1981). This low ratio could indicate diminished contributions of land plant matter, enhanced contributions of algal hydrocarbons, or insufficient time for degradation of the algal hydrocarbons, which typically are more easily degraded than are land plant waxes (Giger et al. 1980; Cranwell 1984). Mass accumulation rates of land plant hydrocarbons do not systematically decrease in younger sediments; however, the rates of algal hydrocarbons do increase (Table 1). The change to lower $\mathrm{C}: \mathbf{N}$ ratios and larger $\delta^{15} \mathrm{~N}$ values in the recent sediments of core 93 suggests that the modern decrease in the land: lake $n$-alkane ratio reflects delayed degradation of the algal components and not increased algal productivity. Because sediments of this age were not recovered in core 96 , we do not know whether this low ratio is a lakewide characteristic of modern hydrocarbon compositions or whether it is a characteristic of the relatively coarse-sized sediments in the shallower parts of Pyramid Lake.

At least part of the fluctuation present in the land: lake ratio in sediments from core 93 seems to record variations in delivery of land-derived hydrocarbons by the Truckee River. Elevated land: lake ratios occur in sediments corresponding to A.D. 1930 and A.D. 1228. The higher ratios are accompanied by larger mass accumulation rates of land-derived biomarker hydrocarbons (Table 1). Larger proportions of land-derived bulk organic matter may have also been delivered to Pyramid Lake at these times. The elevated $\mathrm{C}: \mathrm{N}$ ratio in the sediment horizon corresponding to A.D. 1326 (Fig. 2) is consistent with an increased delivery of landderived organic matter during this period.

$n$-Alkane distributions in lake sediments can also provide an approximate record of watershed plant types. In watersheds where grasses dominate, $n-\mathrm{C}_{31}$ is the major sediment $n$-alkane, whereas $n-\mathrm{C}_{27}$ and $n-\mathrm{C}_{29}$ are more abundant in lake sediments where trees and shrubs dominate (Cranwell 1973). The $n-\mathrm{C}_{31}$ alkane is more abundant than $n-\mathrm{C}_{29}$ in the core interval corresponding to A.D. 1228 in core 93 (Fig. 4). Increases in total land-derived organic matter and in land-derived plant waxes are also indicated in this interval. The evidence that land organic matter contribution synchronously increased and changed to one in which grasses were more important hints that the climate may have briefly been wetter between A.D. 1200 and 1400. This explanation means that the enhanced $\Delta \delta^{13} \mathrm{C}$ at this sediment horizon (Fig. 3) cannot result from lowered lake level and instead may reflect a change in algal assemblage.

Meyers et al. (1980) used the ratio of $\mathrm{C}_{29}$ to $\mathrm{C}_{17} n$-alkanes to evaluate contributions of land-derived and algal hydrocarbons in the sediments of a 1.4-m core collected in $72 \mathrm{~m}$ of water at site 2 (Fig. 1). This land: lake $n$-alkane ratio remained at -5 from the sediment surface to a core depth of $95 \mathrm{~cm}$, similar to the ratio used for core 96 in the central basin, but then increased to nearly 40 between core depths of $105-115 \mathrm{~cm}$. This change to a more land-derived character of $n$-alkane distribution was accompanied by evidence of improved preservation of organic matter in the bottom sediments, presumably because of enhanced sedimentation rates. Greater fluvial delivery of land-derived organic matter and of clastic sediments as a result of a period of wetter climate was postulated to be the cause of these changes. Although the 1976 core was not actually dated, Meyers et al. (1980) estimated that this period of climate change corresponded to A.D. 1300-1400 from sediment trap flux data and by comparison to sedimentation rates measured in Walker Lake, south of Pyramid Lake (Fig. 1). The evidence of a change to wetter climate between 1200 and 1400 in the core 93 sediments agrees with the crude estimate of the timing of the paleoclimate change from the 1976 core.

Sediments of lakes near urban areas often contain evidence of petroleum contamination starting in the late $1800 \mathrm{~s}$ (Meyers 1987). Petroleum hydrocarbons can be distinguished from biological hydrocarbons by two distinctive characteristics - the absence of the characteristic odd-carbon chainlength dominance of biological hydrocarbons, and presence of a more diverse range of molecular structures than is found in biological hydrocarbon mixtures (e.g. Farrington and Meyers 1975). This latter characteristic results in a mixture of hydrocarbon compounds that cannot be separated by even high resolution capillary gas chromatography, giving rise to the term "unresolved complex mixture." The lack of a measurable unresolved complex mixture in any of the chromatograms obtained from the sediment core intervals (Fig. 5) shows that detectable petroleum contamination is absent from Pyramid Lake sediments despite a history of power boat use on the lake.

Our comparisons of sediments from cores obtained from the deepest part of Pyramid Lake and from a location closer to the principal source of water, the Truckee River, revealed temporal and spatial differences in sedimentary organic matter contents. A shift in $\mathrm{C}: \mathrm{N}$ ratios from between 10 and 13 in older sediments to values of $\sim 10$ in modern sediments implies diminished delivery of land-derived organic matter since the onset of river water diversion in 1905. Algal productivity has probably decreased since 1930 because of accompanying diminished delivery of land-derived nutrients. The carbon isotopic compositions of sedimentary organic matter and carbonates has become more depleted in ${ }^{1.3} \mathrm{C}$ since 1905 , and the difference between the $\delta^{1.3} \mathrm{C}$ values of organic and inorganic carbon has become larger. The increase in $\Delta \delta^{13} \mathrm{C}$ probably records changes in algal assemblages in the lake as the water level fell and productivity has decreased. $n$-Alkane biomarker molecules extracted from the sediments are predominantly from land plants, and the relative proportion of land-derived material has decreased since fluvial diversion began in 1905. Changes in organic matter character suggest that an enhanced contribution of land-derived material occurred circa A.D. 1200-1400. A decrease in the alkane biomarker $n-\mathrm{C}_{29}: n-\mathrm{C}_{31}$ ratio indicates an increase in grasses relative to trees and shrubs as a result of a wetter 
climate that prevailed at that time. Sediments closer to the Truckee River contain lower concentrations but have higher mass accumulation rates of organic matter than in sediments from the center of the lake. Different amounts of sorting occur to sediments during their transport and deposition in Pyramid Lake, and the process affects the amounts and types of their organic matter.

\section{Philip A. Meyers} Gabrielle E. Tenzer

Department of Geological Sciences

The University of Michigan

Ann Arbor, Michigan 48109-1063

Martin E. Lebo

Division of Environmental Studies

University of California at Davis

Davis, California 95616

John E. Reuter

Institute of Ecology

University of California at Davis

\section{References}

BENSON, L. V. 1994. Stable isotopes of oxygen and hydrogen in the Truckee River-Pyramid Lake surface-water system. I. Data analysis and extraction of paleoclimatic information. Limnol. Oceanngr. 39: 344-355.

, M. Kashgarian, ANd M. Rubin. 1995. Carbonate deposition, Pyramid Lake subbasin, Nevada. 2. Lake levels and polar jet stream pusitions reconstructed from radiocarbon ages and elevations of carbonates (tufas) deposited in the Lahontan basin. Palaeogeogr. Palaeoclimatol. Palaeoecol. 117: 1-30. , P. A. Meyers, and R. J. Spencer. 1991. Change in the size of Walker Lake during the past 5,000 years. Palaeogeogr. Palaeoclimatol. Palaeoecol. 81: 189-214.

Blumer, M., R. R. L. Guillard, AND T. Chase. 1971. Hydrocarbons of marine plankton. Mar. Biol. 8: 183-189.

Cranwell, P. A. 1973. Chain-length distribution of $n$-alkanes from lake sediments in relation to postglacial environmental change. Freshwater Biol. 3: 259-265.

- 1984. Lipid geochemistry of sediments from Upton Broad, a small productive lake. Org. Geochem. 7: 25-37.

\footnotetext{
' Present address: Weyerhauser Company, P.O. Box 1391, New Bern, North Carolina 28563.

\section{Acknowledgments}

We deeply appreciate the advice, philosophical support, and critical comments of L. V. Benson; such comments helped our study and improved our manuscript. N. E. Ostrom provided thoughtful refinements of the manuscript. B. J. Eadie freely shared with us his laboratory, his expertise, and his experience in nitrogen isotope analysis. Anne Hogge and Payal Parekh assisted in the sediment analyses. We are grateful to $\mathrm{D}$. N. Edgington for providing the ${ }^{210} \mathrm{~Pb}$ dating of the sediment cores. Funding for this study was provided by the Pyramid Lake Paiute Tribe through a Clean Water Act, section 106 grant administered by the U.S. Environmental Protection Agency. We thank the donors of the Petroleum Research Fund, administered by the American Chemical Society, for partial support of this work.
}

- G. Eglinton, AND N. Robinson. 1987. Lipids of aquatic organisms as potential contributors to lacustrine sedimentsII. Org. Geochem. 11: 513-527.

Eglinton, G., and R. J. Hamilton. 1963. The distribution of alkanes, p. 187-217. In T. Swaine [ed.], Chemical plant taxonomy. Academic.

— AND - 1967. Leaf epicuticular waxes. Science 156: $1322-1335$.

Emerson, S., And J. I. Hedges. 1988. Processes controlling the organic carbon content of open ocean sediments. Paleoceanography 3: 621-634.

ENGLEMAN, E. E., L. L. JaCkson, AND D. R. NoRTON. 1985. Determination of carbonate carbon in geological materials by the coulometric titration. Chem. Geol. 53: 125-128.

FarRington, J. W., AND P. A. MEYers. 1975. Hydrocarbons in the marine environment, p. 109-136. In G. Eglinton [ed.], Environmental chemistry. V. I. Chemical Society (U.K.).

Fogel, M. L., AND L. A. Cifuentes. 1993. Isotope fractionation during primary production, p. 73-98. In M. H. Engel and S. A. Macko [eds.] Organic geochemistry: Principles and applications. Plenum.

Galat, D. L. 1986. Organic carbon flux to a large salt lake: Pyramid Lake, Nevada, U.S.A. Int. Rev. Ges. Hydrobiol. 71: 621654.

- AND R. L. JACOBSEN. 1985. Recurrent aragonite precipitation in saline-alkaline Pyramid Lake, Nevada. Arch. Hydrobiologia 105: 137-159.

Giger, W., C. Schaffner, and S. C. Wakeham, 1980. Aliphatic and olefinic hydrocarbons in recent sediments of Greifensee, Switzerland. Geochim. Cosmochim. Acta 44: 119-129.

Goossens, H., C. Duren, J. W. De Lefuw, and P. A. Schenck. 1989. Lipids and their mode of occurrence in bacteria and sediments-II. Lipids in the sediment of a stratified, freshwater lake. Org. Geochem. 14: 27-41.

Hollander, D. J., AND J. A. McKenzile. 1991. $\mathrm{CO}_{2}$ control on carbon-isotope fractionation during aqueous photosynthesis. A paleo- $\mathrm{pCO}$ barometer. Geology 19: 929-932.

Hostetler, S. W., F. Giorgi, G. T. Bates, and P. J. Barti.ein. 1994. Lake-atmosphere feedbacks associated with paleolakes Bonneville and Lahontan. Science 263: 665-668.

Lebo, M. E., And J. E. Reuter. 1995. Spatial variability in sedimont composition and evidence for resuspension in a large, deep lake. Mar. Freshwater Res. 46: 321-346.

- - - AND P. A. Meyers. 1994. Historical changes in sediments of Pyramid Lake, Nevada, USA: Consequences of changes in the water balance of a terminal desert lake. J. Paleolimnol. 12: 87-101.

C. L. Rhodes, and C. R. Goldman. 1993. Pyramid Lake, Nevada, water quality study 1989-1993. V. II. Limnological Description. Univ. California-Davis.

Leenheer, M. J., K. D. Flessland, and P. A. Mtytirs. 1984. Comparison of lipid character of sediments from the Great Lakes and the northwestern Atlantic. Org. Geochem. 7: 141150.

MEYERS, P. A. 1987. Chronic contamination of lakes by petrolcum hydrocarbons: The sedimentary record, p. 149-160. In J. H. Vandermeulen and S. E. Hrudy [eds.], Oil in freshwater: Chemistry, biology, countermeasure technology. Pergamon.

- 1994. Preservation of elemental and isotopic source identification of sedimentary organic matter. Chem. Geol. 114: 289-302.

- AND B. J. EADIE. 1993. Sources, degradation and recycling of organic matter associated with sinking particles in Lake Michigan. Org. Geochem. 20: 47-56.

- AND R. ISHIWATARI. 1993. Lacustrine organic geochem- 
istry - an overview of indicators of organic matter sources and diagenesis in lake sediments. Org. Geochem. 20: 867-900.

, H. B. Maring, AND R. A. BOURbonniere. 1980. Alkane and alkanoic acid variations with depth in modern sediments of Pyramid Lake, p. 365-374. In A. G. Douglas and J. R. Maxwell [eds.], Advances in organic geochemistry 1979. Pergamon.

O'LeARY, M. H. 1988. Carbon isotopes in photosynthesis. BioScience 38: 328-336.

Peters, K. E., R. E. Sweeney, and I. R. Kaplan. 1978. Correlation of carbon and nitrogen stable isotope ratios in sedimentary organic matter. Limnol. Oceanogr. 23: 598-604.

Peterson, B. J., R. W. Howarth, and R. H. GarritT. 1985. Multiple stable isotopes used to trace the flow of organic matter in estuarine food webs. Science 227: 1361-1363.
Rieley, G., R. J. Collier, D. M. Jones, and G. Eglinton. 1991. The biogeochemistry of Ellesmere Lake, U.K. I. Source correlation of lcaf wax inputs to the sedimentary lipid record. Org. Geochem. 17: 901-912.

Tenzer, G. E., P. A. Meyers, and P. A. KnOoP. 1997. Sources and distribution of organic and carbonate carbon in surface sediments of Pyramid Lake, Nevada. J. Sed. Res. 67: 884-890.

WEETE, J. D. 1976. Algal and fungal waxes, p. 349-418. In P. E. Kolattukudy [ed.], Chemistry and biochemistry of natural waxes, Elsevier.

\section{Copepod mortality induced by fluctuating levels of natural ultraviolet radiation simulating vertical water mixing}

\begin{abstract}
The effect of fluctuating ultraviolet radiation levels on the copepod Boeckella gracilipes was investigated in Lake Escondido (Patagonia, Argentina). The animals were incubated either at fixed depths or rotating in in situ plankton wheels of different diameters. The observed mortality was significantly higher in rotating trcatments. Static incubations can be used to predict the mortality of vertically moving $B$. gracilipes, providing that the doses of UVA and UVB are known. The results suggest that under moderate wind conditions, the plankton of shallow lakes are exposed to potentially damaging levels of solar radiation, even in relatively turbid waters.
\end{abstract}

Natural solar radiation is now recognized as a strong selective force in aquatic ecosystems. Although much of the recent work on UV photobiology has been stimulated by future prospects of increases in UVB intensities due to stratospheric ozone depletion, the accumulated evidence demonstrates that UV levels considered normal have significant impacts on natural communities (Williamson 1995).

Recent studies using newly developed submersible radiometers have identified dissolved organic carbon (DOC) concentration as the most important factor controlling the attenuation of ultraviolet radiation (UVR) in lakes (Scully and Lean 1994; Morris et al. 1995; Morris and Hargreaves 1997). It has also been suggested that changes in DOC concentration may be more important than stratospheric ozone depletion in regulating future changes in UVR in natural freshwater ecosystems (Schindler et al. 1996; Williamson et al. 1996).

The physical processes controlling UVR penetration in freshwaters are reasonably well understood (Kirk 1994). In addition, the use of biological dosimeters (Karentz and Lutze 1990; Regan et al. 1992; Kirk et al. 1994) and in situ incubations of planktonic organisms (Williamson et al. 1994; Zagarese et al. 1994) have helped in understanding the at- tenuation of the potential damage with depth. However, damage assessment is complicated by the fact that planktonic organisms may experience tremendous fluctuations in the level of radiation because of their vertical displacements. (Helbling et al. 1994; Jeffrey et al. 1996). Wind stress is usually responsible for turbulent mixing in surface waters (Imboden and Wuiest 1995). In Patagonia (Argentina), the mean wind speed during spring and summer is $32 \mathrm{~km} \mathrm{~h}^{-1}$, and strong winds $\left(>43 \mathrm{~km} \mathrm{~h}^{-1}\right)$ blow $41 \%$ of the days of the year (Baigún and Marinone 1995).

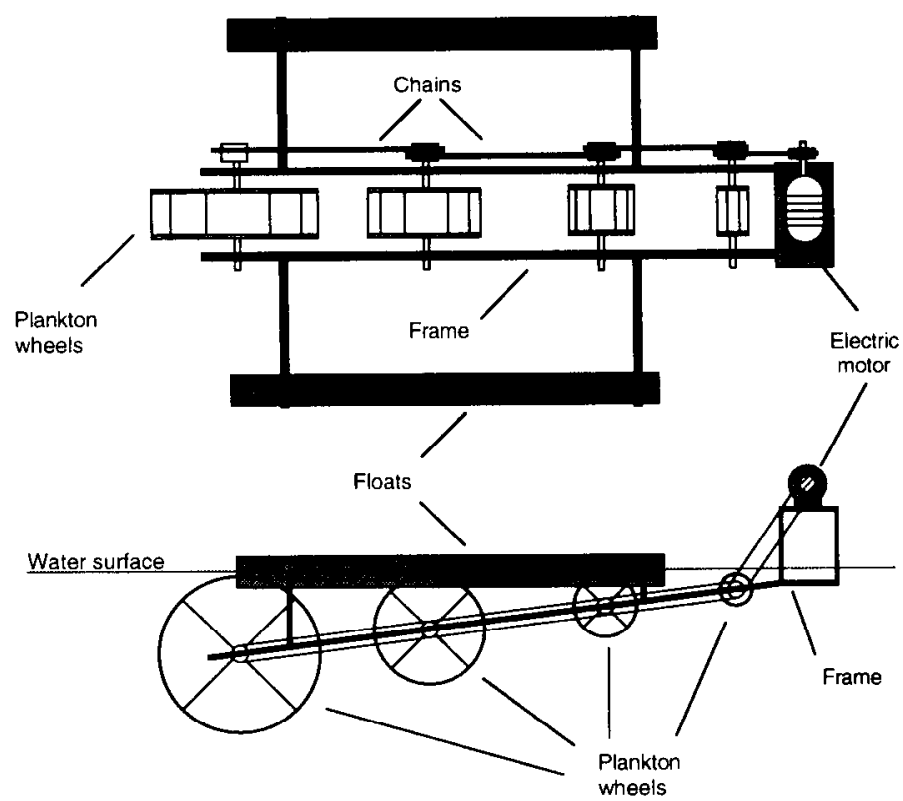

Fig. 1. Top view and side view of the incubation apparatus (see description in text). 